MINERALOGIA, 43, No 3-4: 213-222 (2012)

DOI: 10.2478/v10002-012-0010-6

www.Mineralogia.pl

Mineralogical Society of Poland

Polskie TOWARZYSTWO MINERALOGICZNE

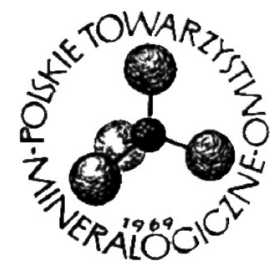

Original paper

\title{
Preliminary results of sulphur isotope studies on sulfides from selected ore deposits and occurrences in the Karkonosze-Izera Massif (the Sudety Mts., Poland)
}

\author{
Wojciech MAYER ${ }^{1 *}$, Mariusz Orion JĘDRYSEK ${ }^{2}$, Maciej GÓRKA ${ }^{2}$, \\ Wojciech DRZEWICKI ${ }^{2}$, Ksenia MOCHNACKA ${ }^{1}$, Adam PIECZKA ${ }^{1}$ \\ ${ }^{I}$ AGH-University of Science and Technology, Faculty of Geology, Geophysics and Environment Protection, al. \\ Mickiewicza 30, 30-059 Kraków, Poland \\ ${ }^{2}$ University of Wroctaw, Faculty of Earth Sciences and Environmental Management, Institute of Geological \\ Sciences, ul. Cybulskiego 30, 50-205 Wroctaw, Poland \\ *Corresponding author: wmayer@geol.agh.edu.pl
}

Received: 30 September, 2011

Received in revised form: January 15, 2013

Accepted: January 25, 2013

Available online: 30 March, 2013

\begin{abstract}
Preliminary sulphur isotope data are presented for selected ore deposits and occurrences in the Karkonosze-Izera Massif, namely, polymetallic mineralization sites at Budniki, Ciechanowice, Izerskie Garby and Sowia Dolina, and the pyrite deposit at Wieściszowice. The data reveal two populations of $\delta^{34} \mathrm{~S}$ values: from 2.74 to $3.95 \%$ (pyrrhotites and pyrites in Sowia Dolina, and some pyrites in Wieściszowice) and from 0.79 to $1.8 \%$ (pyrites in Budniki, Ciechanowice and Izerskie Garby, and some pyrites from Wieściszowice). All of the data are indicative of endogenic sulphur typical of hydrothermal mineralization despite the genetic differences between the sites.
\end{abstract}

Key-words: Karkonosze-Izera Massif, sulphur isotope studies, polymetallic mineralization

\section{Introduction}

The Karkonosze-Izera Massif (KIM) is a complex structure located in the Western Sudetes (SW Poland). It comprises four, highly diversified Neoproterozoic-Palaeozoic metamorphic units: (1) Izera-Kowary, (2) Ješted, (3) South Karkonosze and (4) Leszczyniec that have been interpreted as a pile of Late Devonian to Early Carboniferous nappes (see 
Mazur, Aleksandrowski, 2001). These metamorphic rocks are intruded by the complex Variscan Karkonosze granite dated by various authors using various (mostly isotopic) methods between 304 and 328 Ma (for details, see Pin et al. 1987; Duthou et al. 1991; Kröner et al. 1994; Machowiak, Armstrong 2007).

This paper provides preliminary sulphur-isotope data for samples of ore minerals from selected localities in the KIM. Although any far-reaching conclusions cannot be made at the moment, the authors decided to publish these pilot results because sulphur isotope data from the KIM are rather rare. Research will be continued on samples from other deposits and mineralization sites in the KIM.

\section{Review of ore deposits and mineralization sites in the KIM area}

The Karkonosze-Izera Massif hosts a number of historical ore deposits and mineralization sites (see, e.g. Berg 1913; Petrascheck 1933; Fedak, Lindner 1966; Mochnacka, Pošmourny 1981; Mochnacka et al. 1995; Mochnacka 2000). Our studies were carried out on sulphides from a few selected localities. Pyrites from the Wieściszowice pyrite deposit as well as pyrrhotites and pyrites from the Budniki, Ciechanowice, Izerskie Garby and Sowia Dolina mineralization sites were analyzed. All of these sites are situated in the metamorphic envelope of the Karkonosze granite. For comparison, the sulphur isotope ratio of molybdenite hosted in the porphyritic variety of the Karkonosze granite in the quarry at Szklarska Poręba-Huta was also measured. The ore deposits and occurrences are briefly characterized below. The localities of the deposits are shown on a geological map of the Karkonosze Izera Massif (Fig. 1).

\subsection{The Wieściszowice pyrite deposit}

The pyrite deposit in Wiesciszowice is located in the northern part of the Leszczyniec Unit composed of Early Palaeozoic, MORB-related metabasites and metagranites accompanied by metasediments (for details, see Kryza, Mazur, 1995; Mazur, Aleksandrowski, 2001).

The Wieściszowice deposit has already been described by several authors, as summarized in Jaskólski (1964 and references therein). The N-S-striking ore zone crops out in a belt over $4 \mathrm{~km}$ long and about $200 \mathrm{~m}$ thick, dipping to the east at about $50^{\circ}$ (Nielubowicz 1958). Pyrite, the dominant ore mineral, is accompanied by rare chalcopyrite and bornite, and traces of galena and sphalerite (Oberc-Dziedzic et al. 2011). The pyritebearing schists are cut by hydrothermal quartz veins which host a diversified ore-mineral assemblage of sulphides and sulphosalts (Piestrzyński, Salamon 1977). In addition, a variety of secondary minerals has been described by Parafiniuk (1991).

Detailed petrographic-, mineralogical-, geochemical- and microstructural studies by Oberc-Dziedzic et al. (2011) revealed a variety of schists comprising chlorite, quartz, albite and micas in various proportions, and amphibolites, the protoliths of which were basic-, acid- and intermediate tuffs, tuffites and ocean-floor basalts originally deposited in an immature oceanic rift (Kryza, Mazur 1995). The igneous rocks of the Leszczyniec Unit were subjected to ocean-floor metamorphism whereas the accompanying sediments were altered by hydrothermal, sulphur-carrying solutions derived from adjacent volcanic centers 
(Oberc-Dziedzic et al. 2011). The metabasites in the Leszczyniec Unit have been dated at $505 \pm 5$ and $494 \pm 2 \mathrm{Ma}$ (zircon U-Pb; Oliver et al. 1993) and pyrite from Wieściszowice at 480 Ma (Re-Os; Oberc-Dziedzic et al. 2011). The age of regional metamorphism of the whole Leszczyniec Unit is estimated at 360-340 Ma (Mazur, Aleksandrowski 2001)

The pyrite deposit in Wieściszowice had been intermittently mined between the end of XVIIIth century and the beginning of the XXth century, and again, in the years 1905-1925 (Fedak, Lindner 1966). Exploration carried out in the years 1952-55 was apparently unsuccessful (Nielubowicz 1958). Recently, the open-pit has been incorporated into a landscape park and is an excellent geotourist attraction.

The origin of the Wieściszowice deposit has been the subject of discussion. In the old German literature, it was presented as a sedimentary (pre-Kulm) suite subjected to regional metamorphism (Berg 1913; Petrascheck 1933). Jaskólski (1964) proposed a sedimentaryexhalative, geosyncline-related origin. Our recent studies suggest a volcanic massive sulphides (VMS) model of deposition in an immature rift environment (Oberc-Dziedzic et al. 2011).

\subsection{The Sowia Dolina mineralization site}

Four abandoned adits, three accompanied by dumps, are located in the middle part of the Sowia Dolina (Owl Valley) in Karpacz on the northern slopes of the Karkonosze Range. These are hosted within the metamorphic envelope of the Karkonosze granite (Fig. 1). The host rocks are various hornfelses (for details see Mochnacka et al. 2007) which contain hydrothermal, vein-type and disseminated sulphide mineralization involving pyrrhotite accompanied by pyrite, chalcopyrite, galena, sphalerite, arsenopyrite, marcasite and Ti minerals (Petrascheck 1933; Mochnacka et al. 2007). The mineralization is a product of hydrothermal activity associated with the Karkonosze granite intrusion (Mochnacka et al. 2007).

\subsection{The Budniki mineralization site}

The Budniki locality is a historic uranium exploration camp (Kaczmarek 1959) located on the northern slopes of the Karkonosze Range, within the metamorphic envelope of the Karkonosze granite. The host rocks belong to the Izera-Kowary Unit - the Early Palaeozoic complex of gneisses, schists, amphibolites and marbles deformed in the Late-DevonianEarly Carboniferous (Mazur, Aleksandrowski 2001) and subsequently intruded by the Variscan Karkonosze granite. In Budniki, three adits accompanied by dumps supplied samples of uneconomic, diversified, pyrrhotite-dominated, Ti-oxide-sulphide-arsenide mineralization with trace scheelite and wolframite. The host rocks are amphibolites and quartzo-feldspathic schists, respectively the products of regional metamorphism of bimodal volcanics and acid tuffs (Mochnacka et al. 2008). 


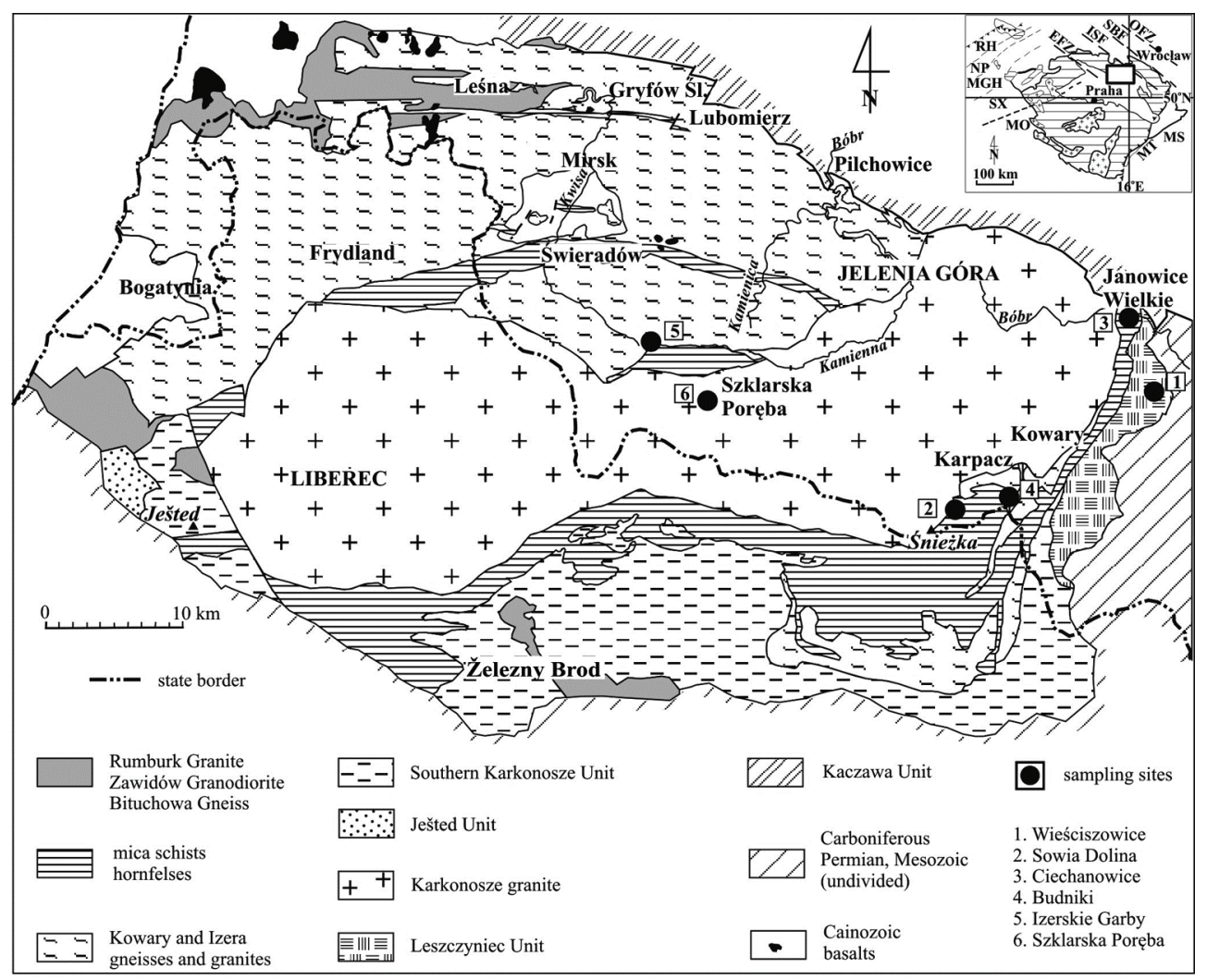

Fig. 1. Locations of selected ore deposits and mineralization sites in the Karkonosze-Izera Massif (simplified after Oberc-Dziedzic et al. 2008): 1. Wieściszowice, 2. Sowia Dolina, 3. Ciechanowice, 4. Budniki, 5. Izerskie Garby, 6. Szklarska Poręba-Huta.

\subsection{The Ciechanowice deposit}

The Ciechanowice deposit is an eastern field of the extended Miedzianka hydrothermal, vein-type, copper-polymetallic ore deposit located in the Izera-Kowary Unit. The deposit is hosted in the northern part of the Czarnów Schist Formation (Teisseyre 1973), close to the contact with the Karkonosze granite and to the Intra-Sudetic Fault.

The geology of the Miedzianka deposits has been described in several extended publications and in a number of contributions, as summarized in Zimnoch (1978) and in Mochnacka et al. (2012). The host-rocks are albite-mica schists, quartzo-feldspathic schists, calc-silicates and amphibolites. These are cut by a multistage system of quartz veins containing chalcopyrite and other $\mathrm{Cu}$ sulphides accompanied by a diversified assemblage of $\mathrm{Fe}, \mathrm{Bi}, \mathrm{Pb}$ and $\mathrm{Co}$, sulphides, arsenides, sulphosalts, native phases, cassiterite and uranium minerals, and a magnetite lens (Zimnoch 1978; Mochnacka et al. 2012). A variety of secondary phases reflect weathering processes. The Miedzianka 
deposits are the result of extended hydrothermal activity associated with the Karkonosze granite.

\subsection{The Izerskie Garby Quarry (“Stanisław” Quarry)}

In the quarry, a huge quartz vein is worked. The vein follows a SW-NE-trending tectonic zone which cuts hornfelses produced from crystalline schists and fine-crystalline Izera gneisses within the contact aureole of the Karkonosze granite (Fila-Wojcicka 2004). The scarce sulphide mineralization of chalcopyrite, pyrite, sphalerite and galena fills cracks in silicified mica schists.

\subsection{The Szklarska Poręba-Huta Quarry}

The Szklarska Poręba-Huta Quarry is a well-known site of diversified although uneconomic, vein-type and disseminated ore mineralization within the Karkonosze granite (see summary in Mikulski 2007; Mayer et al. 2012). Molybdenite occurs in aplogranite hosted in an older, porphyritic variety of the Karkonosze granite (see, e.g. Kryza et al. 2012). This ore mineralization is related to the long-lasting hydrothermal system of the Karkonosze granite intrusion (Mikulski 2007; Mayer et al. 2012).

\section{Analytical procedures}

The sample set includes (Table 1):

- Five concentrates of pyrite separated from pyrite-bearing schists of the Wieściszowice deposit. The same samples, W2, W3, W4, W5a and W5b, were previously subjected to comprehensive mineralogical-, petrographic-, petrogenetic- and geochemical studies (Oberc-Dziedzic et al. 2011).

- Four concentrates of pyrrhotite from samples collected at the old waste dump in Sowia Dolina.

- A single pyrrhotite concentrate from a sample collected at the waste dump in Ciechanowice.

- Four pyrrhotite concentrates from samples collected at the old waste dump in Budniki (upper adit).

- Three pyrite concentrates from samples collected from the Izerskie Garby quartz quarry,

- A single molybdenite sample from aplogranite in the Szklarska Poręba-Huta Quarry.

After initial crushing and suspension in distilled water, the samples were subjected to ultrasound disintegration (frequency: ca $22 \mathrm{kHz}$, density: $2-3 \mathrm{~W} / \mathrm{cm}^{2}$ ) followed by liquid clarification. The residuum was multiply rinsed with distilled water, dried at $110^{\circ} \mathrm{C}$, and treated with hot hydrofluoric acid to remove silicates. Pyrite and pyrrhotite grains were hand-picked under a binocular.

Isotope analyses were carried on at the Laboratory of Isotope Geology and Geoecology, University of Wrocław, using the off-line method in accordance with the standard procedure using $\mathrm{V}_{2} \mathrm{O}_{5}$ and quartz sand (Yanigasawa, Sakai, 1983). Measurements of ${ }^{34} \mathrm{~S}{ }^{32} \mathrm{~S}$ ratios were carried out at the Department of Mass Spectrometry, University of Lublin using 
a MI-1305 mass spectrometer (standard: barium sulphate NBS-127, final normalization with the VCDT, analytical error of sulphur isotope determination $<0.2 \%$ ). Isotopeexchange closure temperatures were calculated from the isotope geothermometer equations of Kajiwara and Krause (1971).

TABLE 1

$\delta^{34} \mathrm{~S}$ values for pyrite and pyrrhotite from selected ore deposits and mineralization sites in the Karkonosze-Izera Massif.

\begin{tabular}{lll}
\hline Sample & Mineral & $\delta^{34} \mathrm{~S}[\% \mathrm{]}]$ \\
\hline Budniki 8 & pyrrhotite & 1.6 \\
Budniki 8 & pyrite & 1.3 \\
Ciechanowice & pyrite & 1.8 \\
Izerskie Garby P 2/4 & pyrite & 1.7 \\
Izerskie Garby P 2/1 & pyrite & 1.2 \\
Izerskie Garby P 2/5 & pyrite & 1.1 \\
Sowia Dolina SD 13 & pyrrhotite & 3.8 \\
Sowia Dolina SD G2 HG & pyrrhotite & 4.0 \\
Sowia Dolina SD G1 & pyrrhotite & 3.3 \\
Sowia Dolina SD G1 & pyrite & 3.7 \\
Sowia Dolina SD 9 & pyrrhotite & 3.4 \\
Sowia Dolina SD 9 & pyrite & 2.7 \\
Szklarska Poręba-Huta & molybdenite & 0.8 \\
Wieściszowice W2 & pyrite & 3.3 \\
Wieściszowice W3 & pyrite & 1.8 \\
Wieściszowice W4 & pyrite & 3.0 \\
Wieściszowice W5a & pyrite & 1.6 \\
Wieściszowice W5b & pyrite & 3.2 \\
\hline
\end{tabular}

\section{Results and discussion}

The $\delta^{34} \mathrm{~S}$ values determined for sulphide minerals from selected locations in the Karkonosze-Izera Massif are listed in Table 1. The $\delta^{34} \mathrm{~S}$ values of pyrite from the Wieściszowice deposit reveal variability as three results fall into a narrow range from +3.0 to $+3.3 \%$ and two others are much lower $(+1.6$ and $+1.8 \%$ ). The latter two values fall into the range +1.0 to $+2.2 \%$ measured by Parafiniuk (1996) in unweathered pyrite crystals from this deposit.

Pyrrhotites from Sowia Dolina show similar $\delta^{34} \mathrm{~S}$ values, from +3.3 to $+4.0 \%$. The $\delta^{34} \mathrm{~S}$ of one pyrite sample is similar to that of pyrrhotite $(+3.7 \%$ ) whereas a second pyrite value is lower $\left(+2.7 \%\right.$ ). Pyrrhotite and pyrite from Budniki have similar $\delta^{34} \mathrm{~S}$ values of $+1.5 \%$ and $+1.3 \%$, respectively. Three pyrite samples from the "Stanisław" quartz quarry have $\delta^{34} \mathrm{~S}$ values ranging from +1.1 to $+1.7 \%$. A single pyrite analysis from Ciechanowice gives a $\delta^{34} \mathrm{~S}$ value of $+1.8 \%$ and a single result from molibdenite in the Karkonosze granite at 
Szklarska Poręba-Huta provides a value of $+0.8 \%$. This last value is the lowest of all determined in this study.

The $\delta^{34} \mathrm{~S}$ data for pyrite and pyrrhotite preclude any determination of formation temperatures except for sample SD 9 from the Sowia Dolina where pyrite and pyrrhotite appear to be in isotopic equilibrium. The $\delta^{34} \mathrm{~S}_{\text {pyrite-pyrhotite }}$ for this pair gives an isotopicexchange closure temperature of $639.71^{\circ} \mathrm{C}$, approximating that of sulphide formation.

In earlier sulphur isotope studies on sulphides in the Karkonosze Izera Massif, Berendsen et al. (1987) reported $\delta^{34} \mathrm{~S}$ values for pyrite and pyrrhotite from the tin-bearing schists of the Stara Kamienica Range ranging between +0.6 and $+11.3 \%$ except for one extreme value of $-51.9 \%$. Mikulski (2010) found $\delta^{34} \mathrm{~S}$ values from +0.07 to $+4.33 \%$ or arsenopyrite, pyrite, pyrrhotite and chalcopyrite from the Czarnów polymetallic deposit, interpreted as reflecting a post-magmatic origin for the sulphur with some contribution from a crustal source.

Our studies revealed $\delta^{34} \mathrm{~S}$ values from +3.8 to $+0.8 \%$ (Table 1 ). The highest values $(>+3.0 \%)$ characterize pyrrhotites and pyrites from the Sowia Dolina site and three pyrites from the Wieściszowice deposit. Pyrrhotite and pyrite from the Budniki, Ciechanowice and Izerskie Garby sites, and two pyrites from the Wieściszowice deposit have distinctly lower $\delta^{34} \mathrm{~S}$ values from +1.1 to $+1.8 \%$. A single $\delta^{34} \mathrm{~S}$ value of $+0.8 \%$ for molibdenite from the Karkonosze granite is exceptionally low in this dataset.

Our results fall into the range of $\delta^{34} \mathrm{~S}$ values obtained by Berendsen et al. (1987) for ore minerals linked genetically to the Variscan Karkonosze granite and to values published by Mikulski (2010) for hydrothermal mineralization deemed to be related to both the Karkonosze granite and to older magmatic episodes. Moreover, our results are consistent with general $\delta^{34} \mathrm{~S}$ values quoted by Barnes (1997) and Misra (2000) for the VMS and hydrothermal vein-type deposits. Unfortunately, at the present stage of sulphur isotope studies on the KIM mineralization, it is impossible to determine the origin of sulfur.

The limited studies to date suggest that the $\delta^{34} \mathrm{~S}$ values measured do not depend on the minerals studied (pyrite or pyrrhotite) and are unrelated to particular host-rock types. Moreover, there seems to be no relation between $\delta^{34} \mathrm{~S}$ and distance from the Karkonosze granite in the case of the sites at Budniki, Ciechanowice, Izerskie Garby and Sowia Dolina. The lowest $\delta^{34} \mathrm{~S}$ value relates to the in-granite molybdenite from the Szklarska Poręba-Huta Quarry. As all mineralizations are genetically related to the hydrothermal system of the Variscan Karkonosze granite (Fila-Wójcicka 2004; Mochnacka et al. 2007, 2008, Mochnacka et al. 2012), some isotope fractionation can be expected around the granite intrusion. The Wieściszowice deposit, which is much older than the mineralization associated with the Karkonosze granite system and which represents a different, VMSrelated genetic type (Oberc-Dziedzic et al. 2011) has two consistent $\delta^{34} \mathrm{~S}$ populations, one lower $(+1.6$ and $+1.8 \%$ o $)$ and one higher $(3.0,3.2$ and $3.3 \%$ ).

The data from the Wieściszowice pyrite deposit are consistent with those for the somewhat genetically similar Iberian Pyrite Belt (IPB) in which $\delta^{34} \mathrm{~S}$ values range from -26 to $+10 \%$ depending on the texture of ore (e.g. Valesco et al. 1998). The $\delta^{34} \mathrm{~S}$ values from Wieściszowice fit best with those representing the stockwork feeder zone $(+3$ to $+5 \%$ o $)$ of the IPB. Although no feeder zone has been found in the Wieściszowice deposit, the VMS model given by Robb (2005, p. 183) shows stockwork mineralization accompanied by an "alteration zone with disseminated sulphides", which might represent an alternative genetic 
model for the pyrite deposit at Wieściszowice. Obviously, the sulphur-isotope signature of the KIM ore deposits and mineralization sites merits further analysis using modern techniques (see e.g. Jamieson et al. 2006; Sharman et al. 2010).

\section{Conclusions}

Preliminary sulphur-isotope studies of pyrite and pyrrhotite in the Budniki, Ciechanowice, Izerskie Garby, Sowia Dolina and Wieściszowice mineralizations define two populations of $\delta^{34} \mathrm{~S}$ values: from $+2.7-+4.0 \%$ (pyrrhotites and pyrites in Sowia Dolina, and some pyrites in Wieściszowice) and from +0.8 to $+1.8 \%$ (mostly pyrites in Budniki, Ciechanowice, Izerskie Garby and some from Wieściszowice). All values fall within the range typical of endogenic sulphur in hydrothermal mineralizations, including VMS deposits.

Acknowledgements. The research was financed by Project No. 5T12B 03625 of the State Committee for Scientific Research (KBN). Thnaks are due to Anonymus Reviewers for corrections and valuable remarks.

\section{References}

Barnes, H.L. (1997). Geochemistry of Hydrothermal Ore Deposits. New York: John Wiley \& Sons Inc.

Berg, G. (1913). Die Erzlagerstätten der nordlichen Sudeten. Festschrift, XII Allgemaine Deutschen Bergmannstage: Der Bergbau im Osten des Königreichs Preussen, Band I: Beiträge zur Geologie Ostdeutschlands, Mai 1913, (1-47). Breslau: Königl. Preuss. Geologischen Landesanstalt.

Berendsen, P., Speczik, S., \& Wiszniewska, J. (1987): Sulphide geochemical studies of the stratiform tin deposits in the Stara Kamienica Chain (SW Poland). Archiwum Mineralogiczne 2, 31-42.

Duthou, J.L., Couturie, J.P., Mierzejewski, M.P., \& Pin, C. (1991). Oznaczenia wieku granitu Karkonoszy metodą izochronowa, rubidowo-strontową, na podstawie całych próbek skalnych. [Next dating of granite sample from the Karkonosze Mountains using Rb-Sr total rock isochrone method]. Przegladd Geologiczny, 36, 75-79.

Fedak, J. \& Lindner, M. (1966). Metalogeneza Sudetów / Metallogenesis of the Sudetes. Prace Instytutu Geologicznego, 1-214.

Fila-Wójcicka, E. (2004). The geological significance of the Rb-Sr whole rock isochron of hornfelsed schists from the Izerskie Garby Zone, Karkonosze Izera block, southern-west Poland. Acta Geologica Polonica, 54(3): 407-411.

Jamieson, J.W., Wing, B.A., Hannington, M. D., \& Farquhar, J. (2006). Evaluating Isotopic Equilibrium among Sulfide Mineral Pairs in Archean Evaluating Isotopic Eqilibrium among Sulfide Mineral Pairs in Archean Ore Deposits: Case Study from the Kidd Creek VMS Deposit, Ontario, Canada. Economic Geology, 101(5) 1055-1061.

Jaskólski, S. (1964). Złoże łupków pirytonośnych w Wieściszowicach na Dolnym Śląsku i próba wyświetlenia jego genezy / On the origin of pyrite schists at Wieściszowice (Lower Silesia). Annales Societatis Geologorum Poloniae, 34, 29-60.

Kaczmarek, A. (1959). Uranonośność Sudetów. Granit i jego wschodnia osłona / Uranium potential of the Sudety Mts. Granite and its eastern envelope. Unpublished industrial report, the R1 Enterprise, Kowary.

Kajiwara, Y. \& Krause, H.R. (1971). Sulfur isotope partitioning in metallic sulfide systems. Canadian Journal of Earth Sciences, 8, 1397-1408.

Kröner, A., Hegner, E., Hammer, J., Haase, G., Bielicki, K-H., Krauss, M., \& Eidam, J. (1994). Geochronology and Nd-Sm systematics of Lusatian granitoids: significance for the evolution of the Variscan orogen in eastcentral Europe. Geologische Rundschau, 83, 357-376.

Kryza, R. \& Mazur, S. (1995). Contrasting metamorphic paths in the SE part of the Karkonosze-Izera Block (Western Sudetes, SW Poland). Neues Jahrbuch für Mineralogie Abhandlungen, 169, 157-192. 
Kryza, R., Crowley, Q.G., Larionov, A., Pin, C., Oberc-Dziedzic, T., \& Mochnacka, K. (2012). Chemical abrasion applied to SHRIMP zircon geochronology: an example from the Variscan Karkonosze Granite (Sudetes, SW Poland). Gondwana Research, 21(4), 757-767.

Machowiak, K. \& Armstrong, R. (2007). SHRIMP U-Pb zircon age from the Karkonosze granite. Mineralogical Society of Poland Special Papers, 31, 193-196.

Mayer, W., Creaser, R. A., Mochnacka, K., Oberc-Dziedzic, T., \& Pieczka, A. (2012). Isotopic Re-Os age of molybdenite from the Karkonosze granite (Szklarska Poręba-Huta, the Sudetes, SW Poland). Geological Quarterly, 56(3), 505-512.

Mazur, S., \& Aleksandrowski, P. (2001). The Tepla(?)/Saxothuringian suture in the Karkonosze-Izera Massif, Western Sudetes, Central European Variscides. International Journal of Earth Sciences, 90, 341-360.

Mikulski, S.Z. (2007). Metal ore potential of the parent magma of granite - the Karkonosze massif example. In A. Kozłowski, \& J. Wiszniewska (Eds.), Granitoids in Poland. Archivum Mineralogiae Monograph, 1, $123-142$.

Mikulski, S.Z. (2010). Charakterystyka i geneza złotonośnej mineralizacji arsenowo-polimetalicznej w złożu Czarnów (Sudety Zachodnie) / The characteristic and genesis of the gold-bearing arsenic polymetallic mineralization in the Czarnów deposit (Western Sudetes). Biuletyn Państwowego Instytutu Geologicznego, 439, 303-320.

Misra, K. C. (2000). Understanding Mineral Deposits. Dordrecht/Boston/London: Kluwer Academic Publishers pp. 1-845.

Mochnacka, K. (2000). Prawidłowości wykształcenia mineralizacji kruszcowej w metamorficznej osłonie granitu Karkonoszy - próba powiązania ze środowiskiem geotektonicznym / Regularities in development of ore mineralization in the metamorphic cover of the Karkonosze granite - an attempt to recognition of geotectonic settings (in Polish). Mineralogical Society of Poland Special Papers, 16, 223-258.

Mochnacka, K., Banaś, M., Kramer, W., \& Pošmourný, K. (1995). Metallogenesis. In: R.D. Dallmeyer et al. (Eds.), Pre-Permian Geology of Central and Eastern Europe, p. VI Western Sudetes (Lugicum). pp. 360-374. Berlin, Heidelberg, New York: Springer.

Mochnacka, K., Oberc-Dziedzic, T., Mayer, W., Pieczka, A., \& Góralski, M. (2007). Occurrence of sulphides in Sowia Dolina near Karpacz (SW Poland) - an example of ore mineralization in the contact aureole of the Karkonosze granite. Mineralogia Polonica, 38(2), 185-207.

Mochnacka, K., Oberc-Dziedzic, T., Mayer, W., \& Pieczka, A. (2008). Ti remobilization and sulphide/sulphoarsenide mineralization in amphibolites: effect of granite intrusion (the Karkonosze-Izera Massif, SW Poland). Geological Quarterly, 52, 349-368.

Mochnacka, K., Oberc-Dziedzic, T., Mayer, W., \& Pieczka, A. (2012). Ore mineralization in the Miedzianka area (Karkonosze-Izera Massif, Sudetes, Poland): new information, Mineralogia, 43(3-4): 155-178.

Mochnacka, K., \& Pošmourný, K. (1981). Metallogenetic characteristics of the Palaeozoic and pre-Palaeozoic formations of the northern part of the Bohemian Massif (Krkonose-Jizerske hory region). Časopis pro Mineralogii a Geologii, 26, 29-43.

Nielubowicz, R. (1958). Problem łupków pirytonośnych w Wieściszowicach / The problem of pyrite-bearing schists in Wieściszowice. Przegląd Górniczy, 14, 541-548.

Oberc-Dziedzic, T., Kryza, R., Pin, Ch., Mochnacka, K, \& Łarionov, A. (2009). The Orthogneiss and Schist Complex of the Karkonosze-Izera Massif (Sudetes, SW Poland): U-Pb SHRIMP zircon ages, Nd isotope systematics and protoliths. Geologia Sudetica, 41, 3-24.

Oberc-Dziedzic, T., Mochnacka, K, Mayer, W., Pieczka, A., Creaser, R.A., \& Góralski, M. (2011). Studies on magnetite and pyrite mineralization, and on their early Paleozoic ocean-floor host-rocks from the Leszczyniec Unit (West Sudetes, Poland). Annales Societatis Geologorum Poloniae, 81, 133-160

Olivier, G.J.H., Corfu, F., \& Krogh, T.E. (1993). U-Pb ages from SW Poland: evidence for a Caledonian suture zone between Baltica and Gondwana. Journal of the Geological Society, 150, 355-369.

Parafiniuk, J. (1991). Fibroferrite, slavikite and pickeringite from the oxidation zone of pyrite-bearing schists in Wieściszowice (Lower Silesia). Mineralogia Polonica, 22(1), 3-13.

Parafiniuk, J. (1996). Sulfate minerals and their origin in the weathering zone of the pyrite-bearing schists at Wieściszowice (Rudawy Janowickie Mts., Western Sudetes). Acta Geologica Polonica, 46, 353-414.

Petrascheck, E. (1933). Die Erzlagerstätten des Schlesischen Gebirges. Archiv für Lagerstättenforschung, 59, 4 53.

Piestrzyński, A., \& Salamon, W. (1977). Nowe dane o polimetalicznej mineralizacji żył kwarcowych w złożu pirytu w Wieściszowicach / New data on polymetallic mineralization of quartz veins in Wieściszowice pyrite deposit. Kwartalnik Geologiczny, 21, 27-35. 
Pin, C., Mierzejewski, M.P., \& Duthou, J.L. (1987). Wiek izochronowy Rb/Sr granitu karkonoskiego z kamieniołomu Szklarska Poręba oraz oznaczenie stosunku inicjalnego ${ }^{87} \mathrm{Sr} /{ }^{86} \mathrm{Sr}$ w tymże granicie / Isochronous age $\mathrm{Rb} / \mathrm{Sr}$ of Karkonosze granite from the quarry Szklarska Poręba Huta and significance of initial ${ }^{87} \mathrm{Sr} /{ }^{86} \mathrm{Sr}$ in this granite. Przeglad Geologiczny, 35, 512-517.

Robb, L. (2005). Introduction to ore-forming processes, Oxford: Blackwell Publishing.

Sharman, E.R., Wing, B.A., Minarik, W.G., Taylor, B.E., \& Dube, B. (2010). Tracing varied fluid sources between VMS deposits by multiple sulfur isotope and trace element analysis. Abstracts of the13 $3^{\text {th }}$ Annual V.M. Goldschmidt Conference, 7-12 September, 2003 (A 942), Kurashiki, Japan.

Teisseyre, J.H. (1973). Skały metamorficzne Rudaw Janowickich i Grzbietu Lasockiego/ Metamorphic rocks of the Rudawy Janowickie and Grzbiet Lasocki. Geologia Sudetica, 8, 7-120.

Valesco, F., Sánchez-Espaňa, J., Boyce, A.J., Fallick, A.E., Sáez, R., \& Almodŏvar, A. (1998). A new sulphur study of some Iberian Pyrite Belt deposits: evidence of a textural control on sulphur isotope composition. Mineralium Deposita, 34, 4-18.

Yanigasawa, F., \& Sakai, H. (1983). Thermal decomposition of barium sulphate-vanadium pentaoxide-silica glass mixtures for preparation of sulphur dioxide for sulphur isotope ratio measurements. Analytical Chemistry, 55, 985-987.

Zimnoch, E. (1978). Mineralizacja kruszcowa złoża Miedzianka w Sudetach / Ore mineralization in the Miedzianka deposit in the Sudetes. Biuletyn Instytutu Geologicznego, 308, 91-124. 